9. Kryvokon' M.O. Osnovni polozhennya reinzhynirynhu ta kontsentratsiyi vyrobnytstva yak instrumentiv antykryzovoho upravlinnya. Hlobal'ni ta natsional'ni problemy ekonomiky. 2014. No. 2. pp. 583-587. [in Ukrainian].

10. Khakymullyna, Ja. F., Fajzullyna A. Gh. Reynzhynyryngh byznes-processov predpryjatyja. Symvol nauky. 2016. No 1 (1). pp. 214-216.

11. Oykhman E. H., Popov E.M. Reynzhynyrynh byznesa, reynzhynyrynh orhanyzatsyy y ynformatsyonnie tekhnolohyy. M. : Fynansi y statystyka. 1997. 333 p. [In Russsian].

12. Vakulenko A. V., Harafonova O. I., Harbuz N. A. Upravlinnya yakistyu : navch. posib. K. : KNEU, 2010. 551 p. [in Ukrainian].

13. Ghevorghjan Z.V. Prymenenye reynzhynyryngha byznes-processov. Эkonomycheskye yssledovanyja y razrabotky. 2017.

No. 4. p. 149-156. [In Russsian].

14. Official website of the company "Tech Mahindra". Available at: www.techmahindra.com (accessed: 22.06.2020).

15. Official website of the company "General Motors". Available at: https://www.gm-city.ru/ (accessed: 22.06.2020).

16. Official website of the company "Dell". Available at: https://clck.ru/L4wQW (accessed: 22.06.2020).

17. Official website of the company "Ford Motor". Available at: https://www.ford.com/ (accessed: 17.06.2020).

18. Official website of the company "IBM". Available at: https://www.ibm.com/ru-ru (accessed: 22.06.2020).

19. Laguna M., Marklund J. Business process modeling, simulation and design. Chapman and Hall/CRC, 2013. 156 p.

Дата подання публікації 20.06.2020 р.

УДК 336.63

Ніколаєва А.М., к.е.н., доцент

Nikolaieva A. Candidate of Economic Sciences, Associate Professor https://orcid.org/0000-0003-3531-2023

Демчук В.В., здобувач першого (бакалаврського)

рівня вищої освіти

Demchuk V., applicant of the first (bachelor's)

level of higher education

\title{
ФІНАНСОВЕ ЗАБЕЗПЕЧЕННЯ РОЗВИТКУ МАЛИХ ПРИВАТНИХ ФІРМ: ТЕОРІЯ ТА ПРАКТИКА
}

\section{Луцьький національний технічний університет}

В статті досліджено економічну сутність дефініції «фінансове забезпечення підприємства». Обгрунтовано, що фінансове забезпечення підприємства розглядається науковцями переважно в контексті складових (методів, функцій) фінансового (фінансово-кредитного) механізму, і пов'язане з мобілізацією та використанням підприємством фінансових ресурсів, які формуються у вигляді грошових фондів чи в не фондовій формі. Авторами узагальнено власне бачення сутності даної дефініції, як діяльності суб’єкта господарювання, пов'язаної з мобілізацією фінансових ресурсів із внутрішніх і зовнішніх джерел, їх розподілом та ефективним використанням на забезпечення безперебійної поточної роботи підприємства та фінансування його розвитку. Виділено фактори впливу на фінансове забезпечення діяльності та розвитку малих підприємств, з урахуванням специфіки їх діяльності, які згруповано у шість груп: масштаби діяльності; виробничий процес; активи, менеджмент; персонал; стійкість.

Основними формами фінансового забезпечення суб'єктів бізнесу в сучасних умовах господарювання виокремлено самофінансування, банківське кредитування, лізингове фінансування, інвестування, бюджетне фінансування, фінансування з різноманітних грошових фондів.

Встановлено, що основними джерелами фінансування діяльності малих приватних транспортних фірм $є$ власні кошти, зокрема нерозподілений прибуток та поточні зобов'язання і забезпечення. Позиковий капітал таких фірм переважно носить короткостроковий характер і складається 3 кредиторської заборгованості та інших поточних зобов'язань, які можна віднести до стійких пасивів.

Проаналізовано сучасні умови фінансового забезпечення розвитку малих приватних транспортних підприємств в Україні. Визначено критерії для прийняття фінансових рішень, а також переваги і недоліки застосування різних форм фінансування оновлення основного капіталу приватних транспортних фірм.

Ключові слова: фінансування, фінансове забезпечення, фінансові ресурси, власний капітал, позиковий капітал, малий бізнес. 


\title{
FINANCIAL SUPPORT FOR THE DEVELOPMENT OF SMALL PRIVATE FIRMS: THEORY AND PRACTICE
}

\author{
Lutsk National Technical University
}

The article examines the economic essence of the definition of «financial security of the enterprise». It is substantiated that the financial support of the enterprise is considered by scientists mainly in the context of the components (methods, functions) of the financial (financial and credit) mechanism, and is associated with the mobilization and use of financial resources. The authors summarize their own vision of the essence of this definition, as the activity of the business entity associated with the mobilization of financial resources from internal and external sources, their distribution and effective use to ensure the smooth running of the enterprise and finance its development. Factors influencing the financial support of the activities and development of small enterprises, taking into account the specifics of their activities, are selected, which are grouped into six groups: the scale of activity; production process; assets, management; personnel; stability.

The main forms of financial support for business entities in modern business conditions are self-financing, bank lending, leasing financing, investing, budget financing, financing from various monetary funds.

It has been established that the main sources of financing for small private transport companies are their own funds, including retained earnings and current liabilities and collateral. The loan capital of such firms is mainly short-term and consists of accounts payable and other current liabilities, which can be attributed to stable liabilities.

The modern conditions of financial support for the development of small private transport enterprises in Ukraine are analyzed. The criteria for making financial decisions, as well as the advantages and disadvantages of using various forms of financing the renewal of fixed assets of private transport companies are identified.

Key words: financing, financial support, financial resources, equity, loan capital, small business.

Постановка проблеми у загальному вигляді i iï зв'язок з важливими науковими та практичними завданнями. Вітчизняним підприємствам малого бізнесу часто доводиться працювати і розвиватися в умовах недостатності власних джерел фінансування, наявності недешевих фінансових ресурсів, що пропонуються на ринку капіталу, та низки додаткових вимог і обмежень, що висуваються до таких фірм кредиторами. Для інвесторів, що мають вільні кошти, фінансування розвитку малого підприємництва не завжди є привабливим, оскільки їх діяльність є більш ризикованою і менш прибутковою, ніж середній і великий бізнес. Тому проблема належного фінансового забезпечення не лише операційної діяльності, але й розвитку малих підприємств є завжди актуальною і потребує постійного вирішення.

Аналіз останніх досліджень, у яких започатковано вирішення проблеми. Дослідженням економічної сутності, форм та джерел фінансового забезпечення підприємств, в т.ч. і малого підприємництва, займалися багато вітчизняних та іноземних науковців. Серед них Л. О. Боцьора [1], О. Д. Василик [2], О. В. Гривківська [3], М. О. Гуцул [4], О. М. Кравчук [5], В. М. Опарін [6], А. М. Поддєрьогін [7], О. В. Прокопець [8], О. Р. Романенко [9], О. О. Терещенко [10], О.Б. Стефанишин [11], В. М. Федосов, С. І. Юрій [12] та ін. Зважаючи на те, що розвиток малого підприємництва відіграє велику роль у розбудові національної економіки, питання належного фінансового забезпечення розвитку діяльності малих підприємств залишаються пріоритетним напрямом і потребують подальшого дослідження.

Цілі статті. Метою статті $є$ дослідження теоретико-прикладних аспектів фінансового забезпечення діяльності та розвитку малих приватних підприємств.

Виклад основного матеріалу дослідження 3 повним обгрунтуванням отриманих наукових результатів. Під час здійснення своєї фінансово-господарської діяльності суб'єктам господарювання доводиться вирішувати проблеми не лише 3 пошуком доступних джерел фінансування, але й вибором напрямів їх ефективного розподілу й використання. Особливо 3 проблемою достатнього фінансового забезпечення стикаються суб'єкти малого бізнесу, вибір джерел фінансування для яких $\epsilon$ обмеженим порівняно з середніми і великими компаніями. Від обсягів і своєчасності фінансування залежить як безперебійність роботи підприємства, його здатність своєчасно здійснювати платежі в бюджет, постачальникам, працівникам, так i 
можливості його подальшого розвитку. Тому проблема фінансового забезпечення діяльності та розвитку підприємств не втрачає своєї актуальності, особливо в сучасних українських реаліях.

Дане питання постійно підіймається в наукових працях вітчизняних та зарубіжних науковців, різних експертів-практиків. Єдиного підходу до дефініції «фінансове забезпечення підприємства» в наукових джерелах ми не зустріли, проте 3'ясували, що це поняття тісно пов'язане і переплітається 3 такими поняттями як «фінансування», «фінансові ресурси», «фінансова діяльність», «фінансовий механізм» (табл. 1). Фінансове забезпечення можна розглядати, перш за все, як процес фінансування суб' єкта господарювання, або процес забезпечення діяльності та розвитку підприємства необхідним обсягом фінансових ресурсів. Все це $\epsilon$ безпосереднім завданням фінансової діяльності фірми і базовими обов'язками іiі фінансових менеджерів.

Таблиця 1

Погляди вчених щодо трактування дефініції «фінансове забезпечення підприємства»

\begin{tabular}{|c|c|c|}
\hline Автори & Економічна сутність & $\begin{array}{c}\text { Форми (елементи, методи) } \\
\text { фінансового забезпечення, що } \\
\text { виділяє автор }\end{array}$ \\
\hline О.Д. Василик & $\begin{array}{l}\text { «Фінансове забезпечення - це функція фінансового } \\
\text { механізму і здійснюється шляхом використання методів } \\
\text { бюджетного фінансування, самофінансування, } \\
\text { кредитування тощо» [2, с. } 102-103] .\end{array}$ & $\begin{array}{l}\text { - бюджетне фінансування; } \\
\text { - самофінансування; } \\
\text { - кредитування тощо. }\end{array}$ \\
\hline О.В. Гривківська & $\begin{array}{l}\text { «Фінансове забезпечення діяльності підприємств } є \\
\text { методом фінансового механізму діяльності підприємств, } \\
\text { який дає змогу сформувати достатні обсяги фінансових } \\
\text { ресурсів для досягнення беззбитковості діяльності, } \\
\text { підвищення ефективності господарювання та зміцнення } \\
\text { національної економіки» [3, с. } 14] \text {. }\end{array}$ & $\begin{array}{l}\text { - самофінансування; } \\
\text { - кредитування; } \\
\text { - цільове фінансування. }\end{array}$ \\
\hline М.О. Гуцул & $\begin{array}{l}\text { «Фінансове забезпечення підприємства - це економічні } \\
\text { відносини, у процесі яких створюються і розподіляються } \\
\text { фонди грошових коштів для забезпечення підприємства } \\
\text { основними та оборотними активами, власними та } \\
\text { залученими фінансовими ресурсами, достатніми для } \\
\text { безперебійного процесу виробництва та реалізації } \\
\text { продукції» [4, с. } 114] .\end{array}$ & $\begin{array}{l}\text { - утворюються під час } \\
\text { заснування підприємства; } \\
\text { - формуються за рахунок } \\
\text { власних та прирівняних до них } \\
\text { коштів; } \\
\text { - мобілізуються на } \\
\text { фінансовому ринку; } \\
\text { - поступають у порядку } \\
\text { розподілу фінансових } \\
\text { надходжень. }\end{array}$ \\
\hline В.М. Опарін & $\begin{array}{l}\text { «Фінансове забезпечення реалізується на основі } \\
\text { встановленої системи фінансування, яке може } \\
\text { здійснюватись у трьох формах: самофінансування, } \\
\text { кредитування, бюджетне фінансування» [6, с. 19]. }\end{array}$ & $\begin{array}{l}\text { - самофінансування; } \\
\text { - кредитування; } \\
\text { - бюджетне фінансування; } \\
\text { - залучення фінансових } \\
\text { ресурсів за допомогою випуску } \\
\text { акцій. }\end{array}$ \\
\hline О.О. Прокопець & $\begin{array}{l}\text { «Фінансове забезпечення полягає у виділенні певної } \\
\text { суми фінансових ресурсів на розв’язання окремих } \\
\text { завдань фінансової політики господарюючого суб’єкта» } \\
{[8, \text { с. 292]. }}\end{array}$ & $\begin{array}{l}\text { - самофінансування; } \\
\text { - кредитування; } \\
\text { - безповоротне фінансування } 3 \\
\text { бюджету. }\end{array}$ \\
\hline О.Р. Романенко & $\begin{array}{l}\text { «Фінансове забезпечення - це покриття витрат за } \\
\text { рахунок фінансових ресурсів, що акумулюються } \\
\text { суб’єктами господарювання і державою» }[9, \text { с. } 18] .\end{array}$ & $\begin{array}{l}\text { - самофінансування; } \\
\text { - кредитування; } \\
\text { - державне фінансування. }\end{array}$ \\
\hline О.Б. Стефанишин & $\begin{array}{l}\text { «...пропонуємо під фінансовим забезпеченням розвитку } \\
\text { розуміти, безпосередньо обсяг і склад (структуру) } \\
\text { фінансових ресурсів, процеси та умови їх надходження, } \\
\text { фінансові взаємовідносини суб'єктів господарювання з } \\
\text { іншими контрагентами, державними органами влади, } \\
\text { фінансово-кредитними інституціями, з урахуванням } \\
\text { ризиків, що виникають під час залучення фінансових } \\
\text { ресурсів, і трактувати його як ключовий чинник } \\
\text { підтримки незворотних кількісних, якісних, системно- } \\
\text { структурних змін - тобто розвитку, а також критерій } \\
\text { оцінювання їх досягнення» [11, с. 49-50] }\end{array}$ & $\begin{array}{l}\text { - самофінансування; } \\
\text { - кредитування; } \\
\text { - бюджетне (державне, } \\
\text { безповоротне); } \\
\text { - донорське; } \\
\text { - додаткове гарантійне; } \\
\text { - фондове (біржове) } \\
\text { фінансування. }\end{array}$ \\
\hline
\end{tabular}


Продовження таблиці 1

\begin{tabular}{|c|c|c|}
\hline 1 & 2 & 3 \\
\hline $\begin{array}{l}\text { С.I. Юрій, } \\
\text { В.М. Федосов }\end{array}$ & $\begin{array}{l}\text { «Фінансове забезпечення - формування цільових } \\
\text { грошових фондів суб’єктів господарювання у } \\
\text { достатньому розмірі та їх ефективне використання» [12]. }\end{array}$ & $\begin{array}{l}\text { - самофінансування; } \\
\text { - кредитування; } \\
\text { - бюджетне фінансування; } \\
\text { - оренда; } \\
\text { - інвестування. }\end{array}$ \\
\hline
\end{tabular}

* Узагальнено авторами.

Взагалі процес фінансування підприємства більшість вчених, серед яких А. М. Поддєрьогін; О. О. Терещенко; В. І. Аранчій, В. Д. Чумак; О. М. Кравчук, В. П. Лещук, і ми з ними згідні, розглядають як «мобілізацію підприємством необхідних для виконання поставлених перед ним планових завдань фінансових ресурсів...» [5, с. 19; 7, с. 14; 10, с. 16 та ін.]. Як показало дослідження літературних джерел, фінансове забезпечення підприємства переважно розглядається науковцями в контексті складових (методів, функцій) фінансового (фінансово-кредитного) механізму, і пов'язане 3 мобілізацією та використанням підприємством фінансових ресурсів, які формуються у вигляді грошових фондів чи в не фондовій формі для забезпечення поточних виробничих потреб підприємства та розвитку його діяльності. Найбільш широко до трактування даної дефініції, на нашу думку, підійшла О. Стефанишин, яка трактує «фінансове забезпечення розвитку з точки зору управлінського підходу» $[11$, с. 50$]$.

В своєму дослідженні автори під фінансовим забезпеченням підприємства розуміють діяльність суб'єкта господарювання, пов'язану з мобілізацією фінансових ресурсів із внутрішніх і зовнішніх джерел, їх розподілом та ефективним використанням на забезпечення безперебійної поточної роботи підприємства та фінансування його розвитку. Фінансові ресурси залучаються, розподіляються і використовуються на підприємствах в процесі реалізації їх фінансових відносин 3 покупцями, постачальниками, капіталодавцями, кредиторами, працівниками, бюджетом, різноманітними державними фондами підтримки розвитку тощо.

Слід відзначити, що серед науковців не прослідковується єдиного підходу до виділення основних видів (методів) фінансового забезпечення. Більшість вчених [1-12] погоджуються, що в ринкових умовах господарювання для підприємств будь-якої форми власності та виду діяльності можливими будуть як мінімум три основні форми (елементи, методи) фінансового забезпечення: «самофінансування (відшкодування витрат на основну діяльність та розвиток підприємств за рахунок власних джерел)» [12]); кредитування (на умовах платності, строковості та повернення отриманих коштів); бюджетне (державне) фінансування (як правило, на безповоротній та безоплатній основі). Проте, слід відмітити, що на теперішній час ринок капіталів дозволяє розширити джерела залучення фінансових ресурсів. Ті кошти, які фірмі вдалося мобілізувати на самому підприємстві, відносять до внутрішнього фінансування (чистий прибуток, амортизаційні відрахування, забезпечення наступних витрат і платежів, виручка від реалізації майна тощо), кошти, які залучені на ринку капіталів, - до зовнішнього фінансування (від випуску акцій, облігацій, отримані кредити тощо).

Розглянемо специфіку та проблеми фінансового забезпечення малих приватних підприємств. Від моменту створення до подальшого свого розвитку діяльність суб' єкта малого підприємництва перебуває під впливом як внутрішніх так і зовнішніх факторів, які здійснюють безпосередній вплив на його фінансове забезпечення (див. рис. 1). Сама специфіка малого підприємництва передбачає здійснення господарської діяльності в умовах дрібного виробництва. У свою чергу, для того, щоб розпочати свою діяльність, залежно від виду діяльності, не всі малі підприємства потребують значної суми стартового капіталу. Заснування підприємства переважно відбувається за кошти 
засновника. Найчастіше це може бути сімейний бізнес. При цьому в законодавчонормативних актах не встановлено рекомендованої мінімальної суми статутного капіталу для малих підприємств. Більшість суб'єктів малого бізнесу реєструють в статуті солідну суму зареєстрованого капіталу, а починають працювати, i, як показує практика, тривалий час працюють 3 наявним неоплаченим капіталом. Значний розмір зареєстрованого капіталу призначений, в першу чергу, для інвесторів і кредиторів, щоб в майбутньому можна було звернутися за додатковим фінансуванням.

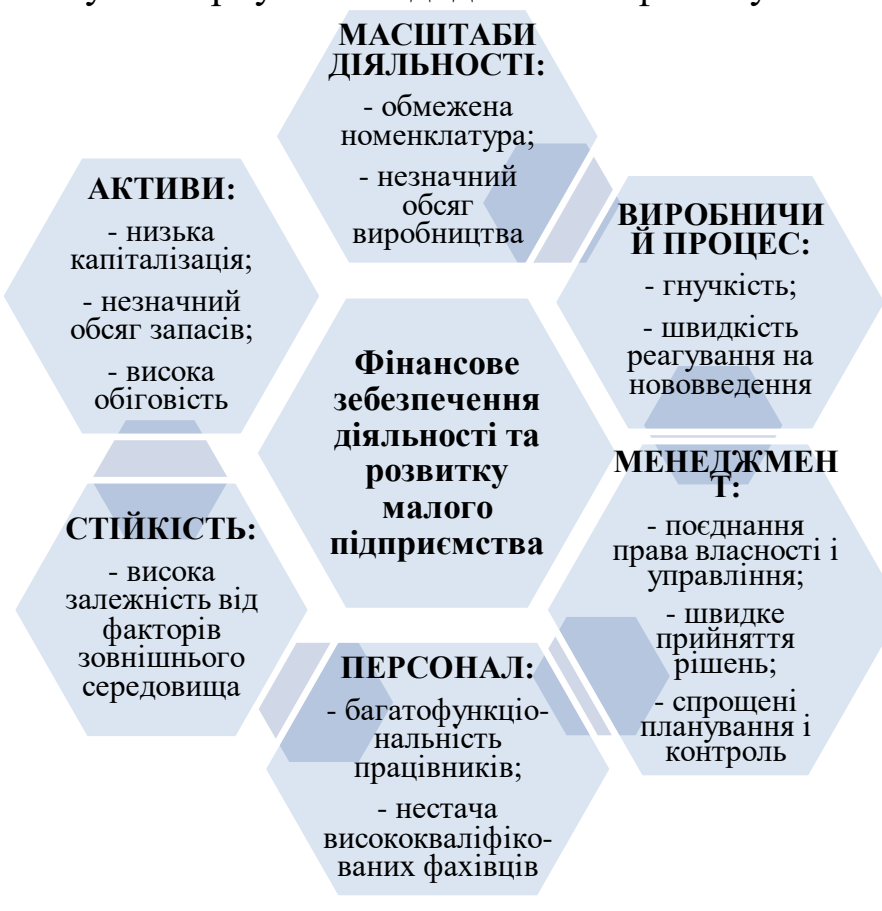

Рис. 1. Фактори впливу на фінансове забезпечення діяльності та розвитку малих підприємств (джерело: узагальнено та складено автором)

Незначні масштаби діяльності малої фірми, а також обмеження предмету іiі діяльності (вузька номенклатура) потребують залучення значно менших фінансових ресурсів, ніж середні та великі компанії, та розпорошення коштів між різними видами діяльності не відбувається. На відміну від великих підприємств, активи малої фірми мають низький рівень капіталізації, кошти не заморожуються надовго в запасах, оборотні активи мають високу обіговість. Позитивним моментом в діяльності таких фірм $\epsilon$ їх швидке реагування на зміни попиту і пропозиції на ринку, відповідно їх виробничий процес має бути гнучким.

Всі фінансові рішення, зокрема i щодо розподілу прибутку, на таких підприємствах приймає його власник (керівник). Зазвичай, фінансове планування i контроль буде мати спрощений характер, як і форма фінансової звітності. У випадку недостатньої компетентності власника чи керівника у сфері фінансових відносин, мале підприємство може отримати (за встановлену плату) всі необхідні консультації щодо складання податкової та фінансової звітності, сплати обов'язкових платежів в бюджет, планування грошових потоків, інвестиційних та інших рішень у «відділі по роботі 3 корпоративними клієнтами обслуговуючого банку, або в спеціалізованих консалтингових чи аудиторських фірмах» [10, с. 21].

Слабким місцем у фінансовому забезпеченні малих приватних підприємств $\epsilon$ обмеженість їхніх можливостей щодо залучення потрібної суми капіталу через інвесторів або банківські кредити. В першу чергу, це через високу ймовірну ризиковість бізнесу (такі підприємства можуть не витримати конкуренції і піти з ринку), незначну 
величину власних коштів, що виступають гарантією повернення кредитів, відсутність належної ліквідної застави чи поручителя, низький рівень доходу на вкладений капітал тощо. Залучення потрібної суми капіталу через випуск власних цінних паперів (акцій, облігацій) для такої форми господарювання $є$ неможливим. Як зазначає український вчений О.О. Терещенко, «фактично неможливе залучення власного капіталу від інших, крім власника, інвесторів» [10, с. 71]. На підставі досліджень узагальнено, що основними джерелами фінансування розвитку малих приватних підприємств є: «внески його власника, тезаврація прибутку, одержання комерційних чи банківських позичок» $[10, \mathrm{c}$. 71].

Проаналізуємо стан фінансового забезпечення суб'єктів малого підприємництва в Україні на прикладі малих приватних транспортних підприємств. За даними офіційної статистики [14], серед підприємств, що належать за КВЕД до виду діяльності «Транспорт, складське господарство, поштова та кур'єрська діяльність», більше 90\% належать до суб'єктів малого бізнесу (табл. 2)

Таблиця 2

Фінансові показники діяльності малих транспортних фірм в Україні*

\begin{tabular}{|c|c|c|c|c|c|c|c|}
\hline Показники & 2013 p. & 2014 p. & 2015 p. & 2016 p. & 2017 p. & 2018 p. & $\begin{array}{l}\text { 3міна за } \\
2018- \\
2013 \text { pp. }\end{array}$ \\
\hline $\begin{array}{l}\text { Кількість малих підпр- } \\
\text { в даного виду } \\
\text { діяльності на кінець } \\
\text { року, од. }\end{array}$ & 15482 & 13757 & 14007 & 12594 & 14140 & 14939 & -543 \\
\hline $\begin{array}{l}\text { В \% до загальної } \\
\text { к-ті підпр-в даного } \\
\text { виду діяльності }\end{array}$ & 92,1 & 92,3 & 92,5 & 91,8 & 92,7 & 92,9 & 0,8 \\
\hline $\begin{array}{l}\text { Фінансовий капітал, } \\
\text { млн грн }\end{array}$ & 42947,2 & 44243,1 & 61377,2 & 136650,7 & 81742,5 & 87255,0 & 44307,8 \\
\hline $\begin{array}{l}\text { Необоротні активи, } \\
\text { млн грн }\end{array}$ & 18288,6 & 18433,5 & 21805,9 & 21715,3 & 32802,1 & 30566,1 & 12277,5 \\
\hline $\begin{array}{l}\text { Власний капітал, } \\
\text { млн грн }\end{array}$ & 9725,5 & $-4499,4$ & $-5851,7$ & $-5430,7$ & 4348,9 & 8715,1 & $-1010,4$ \\
\hline $\begin{array}{l}\text { Коефіцієнт } \\
\text { концентрації власного } \\
\text { капіталу }\end{array}$ & 0,226 & $-0,102$ & $-0,95$ & $-0,040$ & 0,053 & 0,100 & $-0,126$ \\
\hline $\begin{array}{l}\text { Довгострокові } \\
\text { зобов'язання і } \\
\text { забезпечення, } \\
\text { млн грн }\end{array}$ & 6072,2 & 9964,0 & 13090,6 & 11130,9 & 12723,9 & 12363,4 & 6291,2 \\
\hline $\begin{array}{l}\text { Поточні зобов'язання і } \\
\text { забезпечення, млн грн }\end{array}$ & 27125,0 & 38761,0 & 54127,8 & 130937,4 & 64658,6 & 66164,8 & $39,039,8$ \\
\hline $\begin{array}{l}\text { Власний оборотний } \\
\text { капітал, млн грн }\end{array}$ & $-8563,1$ & $-22932,9$ & $-27657,6$ & $-38232,8$ & $-28453,2$ & -21851 & $-13287,9$ \\
\hline $\begin{array}{l}\text { Фінансовий результат } \\
\text { до оподаткування, млн } \\
\text { грн }\end{array}$ & $-139,0$ & $-10142,7$ & $-8851,9$ & $-870,0$ & $-3577,2$ & 2550,7 & 2689,7 \\
\hline $\begin{array}{l}\text { Частка збиткових } \\
\text { малих підпр-в, \% }\end{array}$ & 36,3 & 36,4 & 28,3 & 27,9 & 27,9 & 25,4 & $-10,9$ \\
\hline $\begin{array}{l}\text { Рентабельність } \\
\text { (збитковість) } \\
\text { операційної діяльності, } \\
\%\end{array}$ & 1,8 & $-18,8$ & $-10,8$ & 1,7 & $-2,4$ & 4,4 & 2,6 \\
\hline $\begin{array}{l}\text { Рентабельність } \\
\text { (збитковість) всієї } \\
\text { діяльності, \% }\end{array}$ & $-1,2$ & $-23,2$ & $-15,7$ & $-2,2$ & $-5,2$ & $-2,2$ & $-1,0$ \\
\hline
\end{tabular}

* Складено авторами за даними офіиійної статистики для малих підприємств виду економічної діяльності згідно з КВЕД - «Транспорт, складське господарство, поштова та кур'єрська діяльність» [14]. 
Як показало дослідження, в цілому загальні джерела фінансування таких підприємств (фінансовий капітал) з 2013 р. поступово зростали і на кінець 2016 року складали 136,65 млрд грн, після чого зазнали зменшення і на кінець 2018 року сукупний фінансовий капітал таких підприємств зменшився в 1,6 рази. Ці зміни були обумовлені переважно змінами величини позикового капіталу в складі фінансового капіталу. Як демонструють дані табл. 2, приватні транспортні фірми фінансують свою діяльність переважно за рахунок поточних зобов'язань та забезпечень, а саме кредиторської заборгованості та інших поточних зобов'язань.

Власні кошти серед джерел фінансування займають не значну частку $(10 \%$ на кінець 2018 р.) і більшість періодів становили від’ємну величину, що свідчить про наявність або непокритих збитків або неоплаченого капіталу в складі власного капіталу підприємства. Як свідчать дані статистики, четверта частина малих підприємств даного виду діяльності є збитковою. У підприємств, у яких власний капітал додатній, основними власними джерелами фінансування бізнесу є кошти засновника (зареєстрований капітал) та нерозподілений прибуток, Досить часто $є$ ситуація, коли приватні фірми довгий час провадять свою діяльність 3 наявним неоплаченим капіталом, який значно зменшує власні кошти по балансу, призводячи до їх від'ємної величини. На відміну від інших форм організації бізнесу (ТзОВ, АТ), «приватні підприємства, згідно із законодавством, можуть вести свій бізнес за умови неповністю сформованого статутного капіталу» [13].

Наявність від'ємної величини власного оборотного капіталу на таких підприємствах означає, що вільних власних коштів в обороті підприємств не було, тобто, всі оборотні активи фінансувалися за рахунок поточних зобов'язань і забезпечень. Отже, ситуацію з фінансовим забезпеченням активів малих приватних транспортних фірм в Україні вважаємо незадовільною, оскільки власних коштів не вистачало навіть на формування повної вартості необоротних активів, і їх необхідно було дофінансовувати за рахунок короткострокових залучених коштів. Слід також зазначити, що на підприємствах є проблеми з дотриманням рівня фінансової рівноваги, коли строки, на які мобілізуються фінансові ресурси, не узгоджені зі строками, на які вони вкладаються в оборотні і необоротні активи [10, с. 490-491]. 3 таблиці 2 випливає, що наявних на підприємстві довгострокових пасивів (власного капіталу та довгострокових зобов'язань і забезпечень) не вистачало для формування повністю всіх необоротних активів. У свою чергу, короткострокових активів (оборотних коштів) не вистачало для покриття всіх поточних зобов'язань фірми.

В результаті дослідження виявлено, що джерелами фінансування розвитку приватних транспортних фірм, зокрема, придбання основних засобів (рухомого складу), можуть бути власні кошти підприємства (кошти засновника; нерозподілений прибуток, кошти амортизаційного фонду). За умови недостатності власних коштів, чи небажання власника фірми виводити їх 3 обороту, такі підприємства можуть використати для придбання транспортних засобів інші форми фінансування, зокрема банківський кредит чи лізингову форму фінансування.

За офіційними даними Приватбанку [14-15] нами було проаналізуємо сучасні умови та доцільність використання різних форм фінансування розвитку приватних транспортних фірм. В результаті чого визначено критерії для прийняття фінансових рішень, а також всі можливі переваги і недоліки застосування різних форм фінансування оновлення матеріально-технічної бази малих підприємств (табл. 3).

Таким чином, зваживши всі переваги і недоліки різних форм фінансування придбання необхідної техніки, рекомендовано приватним транспортним фірмам розглядати умови договору фінансового лізингу, що пропонуються різними банками та вибирати найоптимальніший варіант. 
Таблиця 3

Переваги (+) та недоліки (-) різних форм фінансування придбання техніки для малих підприємств

\begin{tabular}{|c|c|c|c|}
\hline \multirow{2}{*}{$\begin{array}{c}\text { Критерій прийняття } \\
\text { рішення }\end{array}$} & \multicolumn{3}{|c|}{ Форми фінансування } \\
\hline & Самофінансування & Фінансовий лізинг & Банківський кредит \\
\hline $\begin{array}{l}\text { 1. Швидкість отримання } \\
\text { техніки }\end{array}$ & $\begin{array}{c}\text { (-) залежить від наявності } \\
\text { власних коштів }\end{array}$ & $\begin{array}{c}(+) \text { швидке отримання } \\
\text { потрібної техніки }\end{array}$ & $\begin{array}{c}(+) \text { швидке отримання } \\
\text { потрібної техніки }\end{array}$ \\
\hline 2. Платність за послугу & $\begin{array}{c}(+) \text { не потрібно } \\
\text { сплачувати відсотки }\end{array}$ & $\begin{array}{c}\text { (-) виплата винагороди } \\
\text { лізингодавцю }\end{array}$ & $\begin{array}{c}\text { (-) сплата відсотків за } \\
\text { кредит }\end{array}$ \\
\hline $\begin{array}{l}\text { 3. Обов'язковість } \\
\text { страхування }\end{array}$ & $(+)$ не обов'язкове & $\begin{array}{c}\text { (-) сплата щорічної } \\
\text { страховки }\end{array}$ & $\begin{array}{c}\text { (-) сплата щорічної } \\
\text { страховки }\end{array}$ \\
\hline 4. Умови розрахунку & $\begin{array}{l}\text { (-) зазвичай під час } \\
\text { купівлі вся сума }\end{array}$ & $\begin{array}{c}+(+) \text { розбито на } 5 \text { років } \\
\text { помісячно рівними } \\
\text { частинами } \\
\end{array}$ & $\begin{array}{c}+(+) \text { розбито на } 5 \text { років } \\
\text { помісячно рівними } \\
\text { частинами } \\
\end{array}$ \\
\hline $\begin{array}{l}\text { 5. Джерело виплати за } \\
\text { придбання техніки }\end{array}$ & $\begin{array}{c}\text { (-) за рахунок власного } \\
\text { капіталу фірми, } \\
\text { додаткових коштів } \\
\text { засновника }\end{array}$ & $\begin{array}{c}\text { (+) виплати за рахунок } \\
\text { прибутку від іï } \\
\text { використання }\end{array}$ & $\begin{array}{c}(+) \text { виплати за } \\
\text { рахунок прибутку від } \\
\text { іiі використання }\end{array}$ \\
\hline $\begin{array}{l}\text { 6. Прийняття рішення } \\
\text { щодо відповідності } \\
\text { умовам фінансування }\end{array}$ & $\begin{array}{c}\text { (+) рішення приймає } \\
\text { фірма (власник фірми) }\end{array}$ & $\begin{array}{l}\text { (-) рішення приймає } \\
\text { лізингодавець }\end{array}$ & $\begin{array}{c}\text { (-) рішення приймає } \\
\text { банк }\end{array}$ \\
\hline $\begin{array}{l}\text { 7. Виведення коштів } 3 \\
\text { обороту }\end{array}$ & $\begin{array}{c}\text { (-) виведення з обігу } 100 \% \\
\text { вартості покупки }\end{array}$ & $\begin{array}{c}(+) \text { виведення з обігу } \\
\text { авансової оплати (30\% } \\
\text { вартості техніки) }\end{array}$ & $\begin{array}{c}(+) \text { виведення з обігу } \\
\text { авансової оплати (30\% } \\
\text { вартості техніки) }\end{array}$ \\
\hline $\begin{array}{l}\text { 8. Можливість зменшення } \\
\text { оподаткованого прибутку }\end{array}$ & (-) не передбачена & $\begin{array}{c}\text { (+) за рахунок відсотків по } \\
\text { лізингу, комісій та } \\
\text { амортизації }\end{array}$ & $\begin{array}{c}(+) \text { за рахунок } \\
\text { відсотків по кредиту }\end{array}$ \\
\hline $\begin{array}{l}\text { 9. Можливість втрати за } \\
\text { несплату }\end{array}$ & $\begin{array}{c}\text { (-) може бути } \\
\text { накладено стягнення } \\
\text { третіх осіб }\end{array}$ & $\begin{array}{c}(+) \text { не може бути } \\
\text { накладено стягнення } \\
\text { третіх осіб }\end{array}$ & $\begin{array}{c}\text { (-) може бути } \\
\text { накладено стягнення } \\
\text { третіх осіб }\end{array}$ \\
\hline $\begin{array}{l}\text { 10. Наявність } \\
\text { забезпечення чи } \\
\text { поручителя }\end{array}$ & $\begin{array}{c}\text { (+) не потрібна застава чи } \\
\text { поручитель }\end{array}$ & $\begin{array}{c}\text { (-) предмет лізингу, що } \\
\text { передається } \\
\text { лізингоодержувачу на } \\
\text { підставі договору лізингу; } \\
\text { порука }\end{array}$ & $\begin{array}{c}\text { (-) майно, на } \\
\text { придбання якого } \\
\text { оформляється } \\
\text { фінансування; } \\
\text { обов’язкова наявність } \\
\text { мінімум } 1 \text { договору } \\
\text { поруки засновника }\end{array}$ \\
\hline
\end{tabular}

Висновки. Таким чином, ми дослідили, що фінансове забезпечення підприємства - це діяльність суб'єкта господарювання, пов’язана з мобілізацією фінансових ресурсів iз внутрішніх і зовнішніх джерел, їх розподілом та ефективним використанням на забезпечення безперебійної поточної роботи підприємства та фінансування його розвитку. Основними формами фінансового забезпечення суб'єктів бізнесу $\epsilon$ самофінансування, банківське кредитування, лізингове фінансування, інвестування, бюджетне фінансування, фінансування 3 різноманітних грошових фондів. Проте, в сучасних умовах господарювання основним джерелом фінансування як поточної діяльності так і розвитку вітчизняних малих підприємств залишаються власні кошти фірми. Врахування виявлених факторів впливу, а також наведених критеріїв й визначених переваг і недоліків застосування різних форм фінансування, дозволять малим приватним фірмам приймати обгрунтовані фінансові рішення щодо вибору оптимальної для сучасних умов господарювання форми фінансового забезпечення розвитку бізнесу.

\section{Список бібліографічного опису}

1. Боцьора Л.О. Фінансовий механізм розвитку малого підприємництва в Україні : дис. ... канд. економ. наук : 08.00.08. Львів, 2015. 272 с.

2. Василик О. Д. Теорія фінансів. К. : НІОС, 2000. 416 с.

3. Гривківська О. В. Теоретичні підходи до визначення фінансового забезпечення діяльності підприємств. Формування ринкових відносин в Украӥні. 2004. № 2. С. 12-15.

4. Гуцул М. О. Фінансове забезпечення стійкого розвитку підприємства : економічна сутність та особливості. Науковий вісник Херсонського державного університету. Економічні науки. 2016. Вип. 17. Ч. 1. С. 112-115. 
5. Кравчук О. М., Лещук В. П. Фінансова діяльність суб'єктів підприємництва : навч. посіб. К. : Центр учбової літератури, 2010. 504 с.

6. Опарін В.М. Фінанси (загальна теорія) : навч. посіб. 2-ге вид., доп. і перероб. К. КНЕУ, 2002. 240 с.

7. Фінанси підприємств : підручник / Поддєрьогін А. М., Білик М. Д., Буряк Л. Д. та ін.; кер. кол. авт. і наук. ред. проф. А. М. Поддерьогін. 7-ме вид., без змін. К. : КНЕУ, 2008. 552 с.

8. Прокопець О. В. Фінансове забезпечення інвестиційної діяльності підприємств промисловості. Сталий розвиток економіки. 2011. № 1. С. 292-296.

9. Романенко О. Р. Фінанси : підручник. К. : Центр навч. літ-ри, 2004. 312 с.

10. Терещенко О. О. Фінансова діяльність суб’єктів господарювання : навч. посіб. К. : КНЕУ, 2003. 554 с.

11. Стефанишин О.Б. Управління фінансовим забезпеченням розвитку підприємств роздрібної торгівлі : дис. ... канд. економ. наук : 08.00.04. Львів, 2017. 266 с.

12. Фінанси : підручник / за ред. С. І. Юрія, В. М. Федосова. 2-ге вид. переробл. і доповн. К. : Знання, 2012.687 с.

13. Сопко В. В. Бухгалтерський облік капіталу підприємства (власності, пасивів) : навч. посіб. К. : Центр навчальної літератури, 2006. 312 c. URL : https://dt-kt.net/books/book-15/chapter-105/ (дата звернення : 03.06.2020).

14. Офіційний веб-сайт Державної служби статистики України. URL: http://www.ukrstat.gov.ua.

15. Умови отримання лізингу транспорту/спецтехніки / Офіційний сайт ПриватБанку. URL : https://privatbank.ua/business/lizing (дата звернення: 06.06.2020).

16. Кредит «Бізнес-розстрочка» (розширення бізнесу в розстрочку) / Офіційний сайт ПриватБанку. URL : https://privatbank.ua/business/kredyt-biznes-rozstrochka (дата звернення: 06.06.2020).

\section{References}

1. Botsora, L.O. (2015). Finansovyi mekhanizm rozvytku maloho pidpryiemnytstva v Ukraini [Financial mechanism of small business development in Ukraine] (Ph.D. in Econ. Dissertation, Ivan Franko Lviv National University, Lviv. Ukraine). [in Ukrainian].

2. Vasylyk, O. D. (2000). Teoriia finansiv [Theory of finance]. Kiev: NIOS. [in Ukrainian].

3. Hryvkivska, O. V. (2004). Teoretychni pidkhody do vyznachennia finansovoho zabezpechennia diialnosti pidpryiemstv [Theoretical approaches to determining the financial support of enterprises]. Formuvannia rynkovykh vidnosyn v Ukraini [Formation of market relations in Ukraine], 2, 12-15. [in Ukrainian].

4. Hutsul, M. O. (2016). Finansove zabezpechennia stiikoho rozvytku pidpryiemstva : ekonomichna sutnist ta osoblyvosti [Financial support for sustainable development of the enterprise: economic essence and features]. Naukovyi visnyk Khersonskoho derzhavnoho universytetu. Ekonomichni nauky [Scientific Bulletin of Kherson State University. Economic sciences], Vol. 17, P. 1, (pp. 112-115). [in Ukrainian].

5. Kravchuk, O. M., \& Leshchuk, V. P. (2010). Finansova diialnist subiektiv pidpryiemnytstva : navch. posib. [Financial activity of business entities: Tutorial]. Kiev: Center for Educational Literature. [in Ukrainian].

6. Oparin, V. M. (2002). Finansy (zahalna teoriia) : navch. posib. [Finance (general theory): Tutorial], 2-he vyd., dop. i pererob. Kiev: Kyiv National University of Economics. [in Ukrainian].

7. Poddierohin, A. M., \& Bilyk M. D. (Eds.). (2008). Finansy pidpryiemstv : pidruchnyk. [Enterprise finance: a textbook], 7-me vyd., bez zmin. Kiev: Kyiv National University of Economics. [in Ukrainian].

8. Prokopets, O. V. (2011). Finansove zabezpechennia investytsiinoi diialnosti pidpryiemstv promyslovosti [Financial support of investment activity of industrial enterprises]. Stalyi rozvytok ekonomiky [Sustainable economic development], 1, 292-296. [in Ukrainian].

9. Romanenko, O. R. (2004). Finansy : pidruchnyk [Finance: a textbook]. Kiev: Center for Educational Literature. [in Ukrainian].

10. Tereshchenko, O. O. (2003). Finansova diialnist subiektiv hospodariuvannia : navch. posib. [Financial activity of business entities: Tutorial]. Kiev: Kyiv National University of Economics. [in Ukrainian].

11. Stefanyshyn, O. B. (2017). Upravlinnia finansovym zabezpechenniam rozvytku pidpryiemstv rozdribnoi torhivli [Management of financial support for the development of retail trade enterprises] (Ph.D. in Econ. Dissertation, Lviv University of trade and economics, Lviv. Ukraine). [in Ukrainian].

12. Yuriy, S. I., Fedosov, V. M. (2012). Finansy : pidruchnyk [Finance: a textbook]. Kiev: Knowledge. [in Ukrainian].

13. Sopko, V. V. (2006). Bukhhalterskyi oblik kapitalu pidpryiemstva (vlasnosti, pasyviv) : navch. posib. [Accounting of the capital of the enterprise (property, liabilities): Tutorial]. Kiev: Center for Educational Literature. Retrieved from https://dt-kt.net/books/book15/chapter-105/ [in Ukrainian].

14. Ofitsiinyi veb-sait Derzhavnoi sluzhby statystyky Ukrainy [Official website of the State Statistics Service of Ukraine]. Retrieved from http://www.ukrstat.gov.ua. [in Ukrainian].

15. Umovy otrymannia lizynhu transportu/spetstekhniky [Conditions for obtaining a lease of transport / special equipment] / Ofitsiinyi sait PryvatBanku [Official site of PrivatBank]. Retrieved from https://privatbank.ua/business/lizing. [in Ukrainian].

16. Kredyt «Biznes-rozstrochka» (rozshyrennia biznesu $\mathrm{v}$ rozstrochku) [Business installment loan (business expansion by installments)] / Ofitsiinyi sait PryvatBanku [Official site of PrivatBank]. Retrieved from https://privatbank.ua/business/kredyt-biznesrozstrochka. [in Ukrainian].

Дата подання публікації 19.06.2020 р. 